\title{
Severe mucositis without a rash induced by a Mycoplasma pneumoniae infection
}

\author{
Ana Araújo Carvalho 이, ${ }^{1}$ Tiago Milheiro Silva, ${ }^{2}$ Rosario Malheiro, ${ }^{3}$ Maria João Brito ${ }^{2}$
}

${ }^{1}$ Department of Pediatrics, Hospital Dona Estefânia, Lisboa, Portugal

${ }^{2}$ Department of Pediatric Infectious Diseases, Hospital Dona Estefania, Lisboa, Portugal ${ }^{3}$ Department of Pediatric Stomatology, Hospital Dona Estefania, Lisboa, Portugal

\section{Correspondence to} Dr Ana Araújo Carvalho; anacarvalho.fcm@gmail.com

Accepted 11 November 2021

\section{DESCRIPTION}

A 4-year-old boy with a history of autism spectrum disorder presented at the emergency department (ED) after presentation with fever, productive cough and oral lesions for a week, that became progressively worse. On the previous day, swelling of the lips and conjunctival hyperaemia occurred. On the fourth day of illness, he had been diagnosed with atypical pneumonia and was treated with azithromycin, which was stopped by his parents after a single dose. Physical examination revealed hypoxaemia $\left(\mathrm{SpO}_{2} 91 \%\right.$ on room air), dehydration and severe oral mucositis with haemorrhagic ulcers and abundant purulent exudate (figure 1). Ophthalmological evaluation revealed bilateral conjunctival hyperaemia without pseudomembranous conjunctivitis or keratitis. No other mucosal or skin lesions were found. Both cardiac and pulmonary auscultation were normal. A chest X-ray showed a diffuse reticular pattern and laboratory tests revealed normal haemoglobin level, and a normal leucocyte count, along with an elevated neutrophil count $9.91 \times 10^{\wedge} 9 / \mathrm{L}\left(\mathrm{NR} 1.5-8.0 \times 10^{\wedge} 9 / \mathrm{L}\right), \mathrm{C}$ reactive protein $21.7 \mathrm{mg} / \mathrm{L}(\mathrm{NR}<5 \mathrm{mg} / \mathrm{L})$ and erythrocyte sedimentation rate $60 \mathrm{~mm} / \mathrm{h}(\mathrm{NR}<11 \mathrm{~mm} / \mathrm{h})$. He was admitted and commenced on azithromycin, penicillin and clindamycin, as well as supplemental
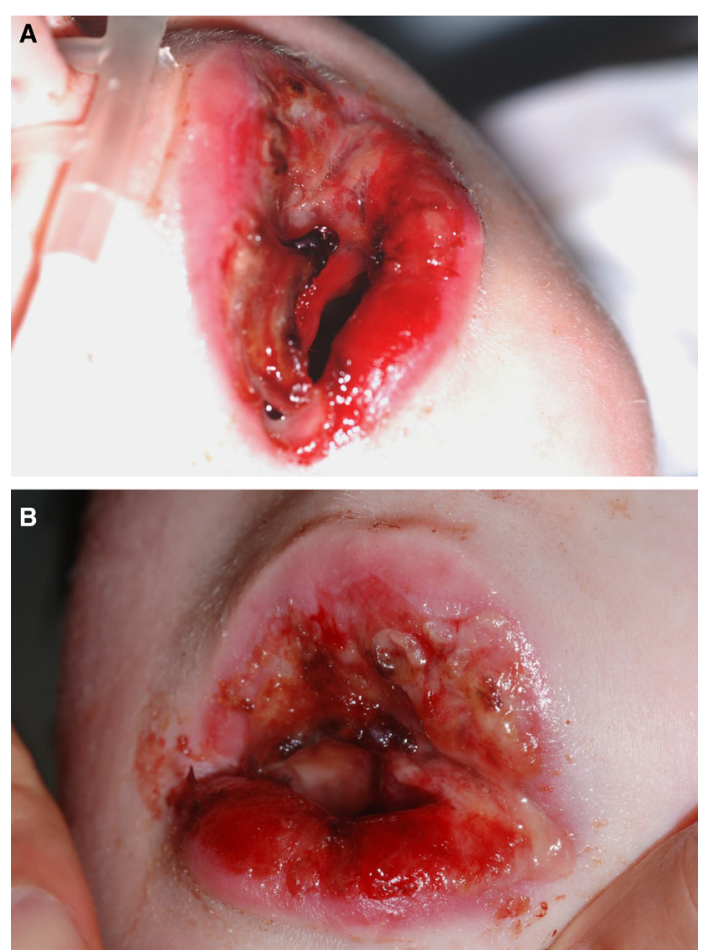

Figure 1 Oral mucositis.

\section{Learning points}

- Mycoplasma pneumoniae can cause extrapulmonary manifestations and new entities have been described, for example Mycoplasma pneumoniae induced rash and mucositis (MIRM).

- When a child presents with mucositis, especially with a clinical history of fever and cough, it is important to considerer MIRM as a possible cause for adequate diagnosis and treatment.

oxygen therapy and parenteral nutrition. The serology for Mycoplasma pneumoniae was suggestive of acute infection (IgM $46 \mathrm{UI} / \mathrm{mL}$ and $\operatorname{IgG} 200$ $\mathrm{UI} / \mathrm{mL}$ ), and a PCR was positive in the respiratory secretions. Blood PCR for herpes simplex virus and PCR for enterovirus in faeces were negative, as well as the blood serology for Epstein-Barr virus and HIV. Treatment included surgical debridement of the oral mucosa twice, a course of immunoglobulin at a dosage of $1 \mathrm{~g} / \mathrm{kg} /$ day for 2 days, and eye lubricants, with complete resolution of his symptoms. Antibiotic therapy included a 5-day course of azithromycin and a 10-day course of intravenous penicillin and clindamycin. The patient was then discharged, 10 days after admission, with substantial clinical improvement.

This case demonstrates a severe extrapulmonary manifestation of $M$. pneumoniae infection. Although this bacterium is a well-recognised cause of respiratory infections, it can also be associated with extrapulmonary complications. ${ }^{1}$ The continuous evidence of the relationship between this bacterium with atypical mucocutaneous presentations has led to the appearance of rare clinical entities like Mycoplasma pneumoniae induced rash and mucositis (MIRM). ${ }^{12}$ In this case, the presence of exclusive mucosal involvement, the evidence of fever and cough before the mucosal disease, the radiological findings of atypical pneumonia as well as the identification of M. pneumoniae enabled the diagnosis of MIRM. This entity is primarily oral and often severe, with scarce or absent skin involvement, ${ }^{2}$ as in our case. No consensus exists about the treatment, although the association between empiric antibiotic therapy and corticosteroids or immunoglobulin is common. ${ }^{3}$ Our patient arrived at the ED with a serious condition, presenting with hypoxaemia, dehydration and severe oral mucositis, and needing surgical debridement and parenteral nutrition. Despite a good prognosis in most 
cases, recurrence or local complications can occur ${ }^{1}$ and, therefore, early recognition and management are essential.

Contributors AAC and TMS started the bibliographic review, outlined the first draft of the article and concluded the subsequent reviews of other authors. RM was responsible for the two surgical interventions and for the writing revision of the stomatological issues in the article. MJB supervised clinical management and was responsible for full writing revision.

Funding The authors have not declared a specific grant for this research from any funding agency in the public, commercial or not-for-profit sectors.

Competing interests None declared.

Patient consent for publication Consent obtained from parent(s)/ guardian(s).

Provenance and peer review Not commissioned; externally peer reviewed.
Case reports provide a valuable learning resource for the scientific community and can indicate areas of interest for future research. They should not be used in isolation to guide treatment choices or public health policy.

\section{ORCID iD}

Ana Araújo Carvalho http://orcid.org/0000-0002-0280-047X

\section{REFERENCES}

1 Canavan TN, Mathes EF, Frieden I, et al. Mycoplasma pneumoniae-induced rash and mucositis as a syndrome distinct from Stevens-Johnson syndrome and erythema multiforme: a systematic review. J Am Acad Dermatol 2015;72:239-45.

2 Santos RP, Silva M, Vieira AP, et al. Mycoplasma pneumoniae-induced rash and mucositis: a recently described entity. BMJ Case Rep 2017;2017:pii:bcr-2017-220768.

3 Olson D, Watkins LKF, Demirjian A, et al. Outbreak of mycoplasma pneumoniaeassociated stevens-Johnson syndrome. Pediatrics 2015;136:e386-94.

Copyright 2021 BMJ Publishing Group. All rights reserved. For permission to reuse any of this content visit

https://www.bmj.com/company/products-services/rights-and-licensing/permissions/

BMJ Case Report Fellows may re-use this article for personal use and teaching without any further permission.

Become a Fellow of BMJ Case Reports today and you can:

Submit as many cases as you like

- Enjoy fast sympathetic peer review and rapid publication of accepted articles

- Access all the published articles

Re-use any of the published material for personal use and teaching without further permission

\section{Customer Service}

If you have any further queries about your subscription, please contact our customer services team on +44 (0) 2071111105 or via email at support@bmj.com.

Visit casereports.bmj.com for more articles like this and to become a Fellow 